Dear Author,

Please, note that changes made to the HTML content will be added to the article before publication, but are not reflected in this PDF.

Note also that this file should not be used for submitting corrections. 


\section{AUTHOR QUERY FORM}

\begin{tabular}{|c|c|c|}
\hline 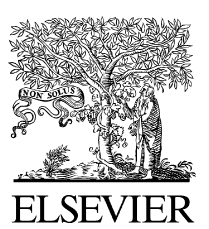 & Article Number: 9596 & $\begin{array}{l}\text { Please e-mail or fax your responses and any corrections to: } \\
\text { E-mail: corrections.eseo@elsevier.tnq.co.in } \\
\text { Fax: }+31204852789\end{array}$ \\
\hline
\end{tabular}

Dear Author,

Please check your proof carefully and mark all corrections at the appropriate place in the proof (e.g., by using on-screen annotation in the PDF file) or compile them in a separate list. Note: if you opt to annotate the file with software other than Adobe Reader then please also highlight the appropriate place in the PDF file. To ensure fast publication of your paper please return your corrections within 48 hours.

For correction or revision of any artwork, please consult http://www.elsevier.com/artworkinstructions.

Any queries or remarks that have arisen during the processing of your manuscript are listed below and highlighted by flags in the proof.

\begin{tabular}{|c|c|}
\hline $\begin{array}{l}\text { Location } \\
\text { in article }\end{array}$ & $\begin{array}{l}\text { Query / Remark: Click on the } Q \text { link to find the query's location in text } \\
\text { Please insert your reply or correction at the corresponding line in the proof }\end{array}$ \\
\hline Q1 & $\begin{array}{l}\text { The following citations "Loach, 2013; Edwards (2013)" are unlisted. Please provide corresponding } \\
\text { references list. }\end{array}$ \\
\hline Q2 & $\begin{array}{l}\text { The citations "Houtman and colleagues (2012); Kaldor and Selchow (2013); Scambler and Kelleher } \\
\text { (1996); Fraser and Honneth, 2003; Houtman et al. (2013); Lyotard, 1971; Castells (2013); Oldenberg, } \\
\text { 1997; Ley and Player (2011)" have been changed to match the author name/date in the reference list. Please } \\
\text { check. }\end{array}$ \\
\hline Q3 & $\begin{array}{l}\text { The reference list mentions Scambler, 2012a and Scambler, 2012b as separate references. Therefore, we } \\
\text { have changed all citations of Scambler, } 2012 \text { to Scambler, 2012a,b. Please amend the text citations if } \\
\text { necessary. }\end{array}$ \\
\hline Q4 & $\begin{array}{l}\text { Please note that there is a mention of 'ADD REFERENCE' in the sentence "the cultural downgrading } \\
\text { of...". Kindly check and provide the citation. }\end{array}$ \\
\hline Q5 & The year in the first occurrence of Scambler, 2012 in the list has been changed to 2012a. \\
\hline Q6 & The year in the second occurrence of Scambler, 2012a in the list has been changed to $2012 \mathrm{~b}$. \\
\hline Q7 & $\begin{array}{l}\text { Uncited references: This section comprises references that occur in the reference list but not in the body of } \\
\text { the text. Please position each reference in the text or, alternatively, delete it. }\end{array}$ \\
\hline Q8 & Please confirm that given names and surnames have been identified correctly. \\
\hline
\end{tabular}




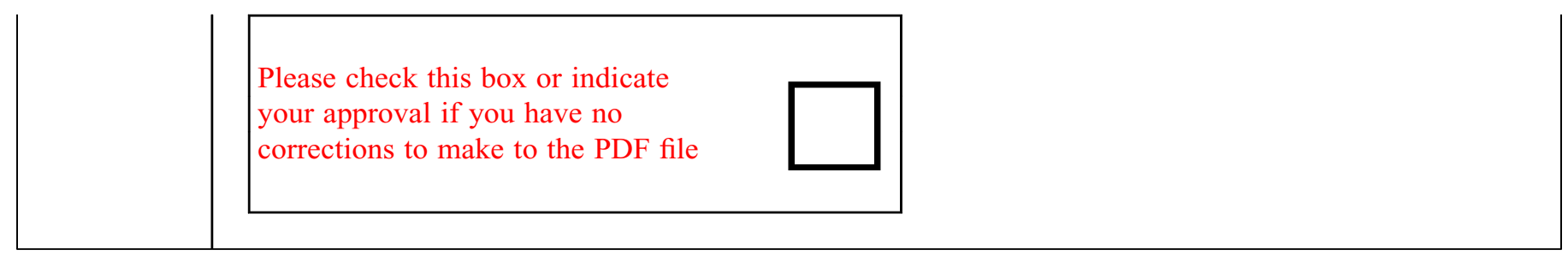

Thank you for your assistance. 


\section{Highlights}

- Revisits civil society in the light of attempts to privatize health care in England.

- A boundary between the 'protest sector' and the lifeworld has become apparent.

- A new class/command dynamic, is leading to oligarchic rule, in financial capitalism.

- Both 'action' and 'foresight sociologies' are advocated in response. 


\title{
Civil society and the Health and Social Care Act in England and Wales: Theory and praxis for the twenty-first century
}

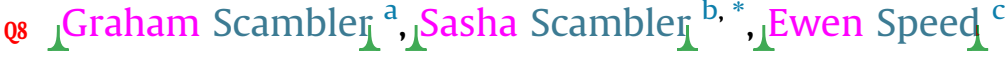 \\ ${ }^{a}$ Research Department of Infection and Population Health, University College London, Mortimer Market Centre, London, WC1E 6JB, UK \\ ${ }^{\mathrm{b}}$ Unit of Social and Behavioural Sciences, King's College London, Caldecot Road, London, SE5 9RW, UK \\ ${ }^{\text {c } S c h o o l ~ o f ~ H e a l t h ~ a n d ~ H u m a n ~ S c i e n c e s, ~ U n i v e r s i t y ~ o f ~ E s s e x, ~ W i v e n h o e ~ P a r k, ~ C o l c h e s t e r, ~ E s s e x, ~ C O 4 ~ 3 S Q ~ U K ~}$
}

\section{A R T I C L E I N F O}

Article history:

Available online $\mathrm{xxx}$

\section{Keywords:}

NHS

Health and Social Care Act

Privatization of health care

Class/command dynamic

Rethinking civil society

Action and foresight sociologies

\begin{abstract}
A B S T R A C T
In this paper we revisit the notion of civil society in the light of recent attempts to privatize health care in England via the passing of the Health and Social Care Act of 2013. This legislation promises a recommodification of the National Health Service (NHS) in England. The Bill was bitterly contested during its passage through parliament, most vigorously in 2011. Much of the opposition occurred at a time of widespread, global rebellion, most notably in the 'Arab uprisings' and through the 'occupy movement'. Despite a plethora of protests, we argue, a non-porous boundary between what we call the 'protest sector' of civil society and the wider public sphere of the lifeworld has become apparent in England. A good deal of collective action, whether campaign-focused (like opposition to the Health and Social Care Bill) or more generalized (like rejections of corporate greed), has so far proved ineffective, at least in the short-term; no crisis of legitimation is apparent. We highlight a new 'class/command dynamic', leading to oligarchic rule, in the present era of financial capitalism. We use this health care case-study to reexamine the notion of civil society and its changing properties in what Castells calls a 'networked society'. The contribution ends with a discussion of the role of the sociologist re-civil society and the advocacy of both 'action' and 'foresight sociologies'.
\end{abstract}

(C) 2014 Published by Elsevier Ltd.

\section{Introduction}

The reform of the National Health Service is, of course, to bring it back into the marketplace and degrade it back into making health care a commodity - so it's not reform at all'.

'If we don't understand that we've got to do everything, up to and including breaking the law, to defend the National Health Service, then we're finished'.

(Quoted by Loach, 2013: ix)

The notions of the public sphere of the lifeworld and civil society are members of a family of concepts. They have been subject to fairly exhaustive review and it is not our intention in this contribution to rehearse this voluminous literature yet again. Rather, we intend to develop a strand of thought and investigation emanating from Habermas' (1989) pioneering socio-historical study of the

\footnotetext{
* Corresponding author.

E-mail addresses: graham.scambler@ucl.ac.uk (G. Scambler), sasha.scambler@kcl. ac.uk, sashascambler@tiscali.co.uk (S. Scambler), esspeed@essex.ac.uk (E. Speed).

emergence - and subsequent decline - of a 'bourgeois' public sphere. We utilize the recent reform of the National Health Service (NHS) in England and Wales to characterize wider changes in civil society. In particular this approach affords us a critical standpoint from which to interrogate these recent reforms, with a view to exploring possible explanations for the relative success of this reform programme in the face of a vociferous and sustained civil society protest. This is interesting in a wider sociological context in the sense that tampering with the NHS was widely perceived, to be politically ill-advised to say the very least. That the coalition government managed to enact such a radical reform programme, (Pollock et al., 2011), in the face of a sustained public campaign against those reforms, with apparently little or no negative effect merits further exploration. In effect, this framing allows us to address a question of how this reform was enacted in face of such pronounced opposition, and to posit a partial explanation drawing upon an observed decline in the possibilities for communicative action across all sectors of civil society.

In the opening paragraphs we sketch Habermas' original analysis, paying particular attention to the conceptual framework within which it is couched and the ways in which it anticipated his later 'mature' works. This allows us to introduce the system/ 
lifeworld dichotomy, strategic versus communicative action, new social movements and so on. We follow this up with a 'refinement' (taking account of a range of criticisms) of Habermas' account of the lifeworld and civil society, which involved a split of the latter into enabling and protest sectors. In the third section we offer a brief characterization of post-1970s financial capitalism, which prepares the ground, in the next section, for an extended case study of the background to and genesis of the Health and Social Care Bill and its transmutation into the Health and Social Care Act of 2013, which effectively (in all but name) privatized the National Health Service in England (see Pollock et al., 2011; Reynolds and McKee, 2012; Davis and Tallis, 2013). In the concluding paragraphs we return to the theoretical domain to address the dialectical relation between theory and research: how might our broadly Habermasian framework help us to understand the contested passage of the Health and Social Care Act and the re-commodification of the NHS in England, and how might our detailed case study inform and suggest theoretical revisions?

\section{From Habermas on the public sphere onwards}

Habermas' analysis of the origins of a European public sphere was presented in a thesis initially rejected by Adorno at Frankfurt but later accepted by Abendroth at Marburg. In it he wrote of the rise of a bourgeois public sphere, initially in England in the eighteenth century and subsequently elsewhere in Europe. The public sphere here represented the public use of reason (as articulated by private individuals engaged in argument that was 'in principle' open and unconstrained). It was a domain in which activities of the state could be confronted and critiqued. The emergence of the public sphere was facilitated, first, by the rise of the periodical press, and second, by the establishment of new centres of sociability like salons and coffee houses. Habermas maintained that this led to a greater accessibility and scrutiny of Parliament and a constitutional extension of rights of freedom of speech and expression. Over time, however, the public sphere experienced a decline (Habermas writes of its 're-feudalisation'). Thompson (1993: 173) summarizes:

'what was once an exemplary forum of rational-critical debate became just another domain of cultural consumption, and the bourgeois public sphere collapsed into a sham world of image creation and opinion management in which the diffusion of media products is in the service of vested interests'.

But this did not address the full complexity of public sphere. Thompson developed a sustained critique, within which he asserts four broad criticisms of Habermas' theorization. Firstly, he neglected non-bourgeois or popular forms of popular discourse and activity, some of which were militantly opposed to bourgeois culture and practice; secondly, he overlooked prior historical examples, notably around the time of the English Civil War in the seventeenth century; thirdly, he underestimated the significance of the absence of women (as feminists have subsequently argued, their absence was constitutive of the public sphere: it was juxtaposed to the private sphere in a gender-specific way); and lastly, he exaggerated both the precipitous nature of the decline of the public sphere and the passivity of later recipients of media products.

These criticisms are compelling, and Habermas (1992) later clarified and/or revised some of the judgements in his early text. Yet his pessimism is still widely shared. In this paper, whilst cognisant of these criticisms, we seek to apply Habermas' notion of the bourgeois public sphere (and its subsequent decline) to offer a critical context in which to interrogate the NHS reforms. While earlier concepts of civil society and the public sphere were pitted against the power of the state, in his neophyte and explicitly Marxist texts Habermas set them in opposition also to the economy. By the time he was writing the public sphere of the lifeworld, (to employ his terminology), had been substantially colonized by the subsystem of the economy as well as that of the state, via their respective steering media of money and power. In the terminology of Habermas $(1984,1987)$, the 'communicative action' characteristic of the lifeworld (oriented to mutual understanding and consensus) had been attenuated, without accountability or redress, by the 'strategic action' characteristic of the system (oriented to outcome alone). For example literature from the turn of the century is replete with references to the vanquishing of what Oldenburg (1997) called 'third places', that is, casual, everyday meeting places like cafes, bars, shopping malls and launderettes. Mayhew (1997) has contributed the thesis that a new cadre of professional specialists, using marketing and promotional campaigns, has come to dominate public communication: he writes of a 'new public', subject to mass persuasion through relentless advertising, lobbying and other forms of media manipulation. Spaces and opportunities for communicative action are in decline whilst spaces and opportunities of strategic action are on the rise.

Four further matters might be mentioned at this point. The first is an elaboration of the Habermasian framework. Habermas positioned civil society at the interface of the private and public spheres of the lifeworld. In Between Facts and Norms he wrote that civil society consists of those 'more or less spontaneously emergent associations, organizations and movements that, attuned to how societal problems resonate in the private life spheres, distil and transmit such reactions in amplified form to the pubic sphere' (Habermas, 1996: 367). Scambler and Kelleher (2006) suggested that two sectors of civil society might be distinguished. What they called the enabling sector of civil society is located in, or derives its impetus from, the private sphere of the lifeworld. It is within the enabling sector that issues of potential concern are first delineated, typically as part and parcel of everyday intercourse and often in Oldenburg's third places. The protest sector of civil society is located in, or is directed towards, the public sphere of the lifeworld. It is within the protest sector that people come together or are mobilized, in networks, campaign groups, social movements and other varieties of association in pursuit of influence (the steering media of the public sphere) for purposeful change (third places are often salient here too). This addendum to Habermas will be utilized later.

A second consideration concerns social movements. Habermas concluded with some reluctance that 'old' class-based movements had ceded territory to 'new' social movements. Producer society had been displaced by consumer society, and collective action had come to focus on identity and belonging rather than the (re)-distribution of material goods. Edwards $(2004,2013)$ argues, we think with justification, that Habermas has become overly ready to write off class politics. Indeed, an excellent study by Houtman et al. (2012) shows that class politics is alive and well but has been compromised by an increase in cross-cutting cultural alignments. Class, we submit, is far from dead even if class-consciousness has for the time being become an unlikely precipitant of collective action.

Third, after the global financial crisis of 2008-9 and the Arab uprisings, there occurred a series of global-to-local protests, campaigns, marches and occupations, many under the umbrella of a broadly anti-capitalist 'movement of movements' In the United Kingdom the foci of discontent embraced the ending of the Education Maintenance Allowance (EMA), (Taylor-Gooby, 2013) the tripling of student fees, (Glennerster, 2013), benefit cuts, corporate tax evasion and avoidance (Farnsworth and Irving, 2012) and, of principal concern here, the Health and Social Care Bill (Davis and Tallis, 2013). Activists engaged under various philosophical and political flags; they were heterogeneous and smart, bound together 
less by what they stood for than by what they were against, Kaldor and Selchow (2012) characterize this as a form of 'Subterranean politics'. This was of course both its strength and its weakness. It was also a scenario beyond old versus new types of social movements, one that combined class based politics with contemporary notions of identity based politics. This has important ramifications for our understanding of civil society.

There have already been some attempts, finally, to address and to theorize the protest sector of civil society into the twenty-first century, most notably by Castells (2012). He writes of networked social movements, an acknowledgement of the rise of 'mass selfcommunication' based on horizontal networks of interactive, multidimensional communication on the Internet and in wireless communication networks. Recent movement activity, he argues, has its origins in structural economic crisis and concomitant crises of legitimation. But they do not just arise from poverty or despair. They share a significant number of properties: they arise spontaneously, usually sparked by anger; they comprise 'networks of networks' (Castells, 2012), typically with de-centred structures involving interaction between multiple nodes; this horizontality of networks lends itself to cooperation and solidarity while mitigating against the need for leadership; they accomplish the transition from outrage to hope by deliberation (Habermas' public use of reason) in autonomous or democratic spaces; they favour nonviolence, typically deploying civil disobedience; they become movements by occupying urban spaces, often local spaces globally connected; they are highly self-reflexive; they are rarely programmatic; they aim at changing the values of society; they are basically political, typically engaging in a form of direct, deliberative democracy born of networked democracy; they generate their own form of 'timeless time' by living in the moment, while opening up the potential for an unlimited horizon of possible futures for those able to access it; and they are 'viral', largely globally accessible and inspirational across modernity's borders and boundaries.

What the work of Castells and others have done is allow for a re-conceptualization of civil society and the public sphere more relevant for the present than its Habermasian and other predecessors. It is a frame we return to, develop and apply later in this contribution.

In terms of our application of Habermas, as our point of departure we accept the utility of the notion of a bourgeois public sphere as the progenitor of a body of critical work that followed. We are interested in its application within a broader context of private and public spheres of the lifeworld, in terms of how this can be used as a means of characterizing civil society. However, Habermas was limited in his application of the public sphere; he was too hasty to delimit its boundaries, and failed to adequately document its subsequent decline (see Thompson, 1993; Oldenburg, 1997, Mayhew, 1997). Whilst we are aware of this critique, and agree with it, it is the concept of the civil society as the interface between the private and public spheres of the lifeworld that is analytically useful for our paper.

Having established this, we propose a number of embellishments to this approach. We seek to further distinguish the role and import and private and public spheres in terms of civil society actions and engagements. Drawing from Scambler and Kelleher (2006), we identify an enabling sector within the private sphere and a protest sector within the public sphere. The enabling sector allows for, or facilitates, the identification of problems and concerns through processes of quotidian interactions. The protest sector then presents the context where people mobilize around those concerns in a very public way.

We also seek to reinvigorate the role that class politics can play in civil society. Neoliberalism and its attendant changes bring with it a decline in class consciousness through a cultural shift (a tacit co-ordination) towards the vested interests of ruling elites (we expand upon this point in the next section of the paper). Our application of Habermas also seeks to take account of the global patterns of resistance that have emerged since the financial crisis of 2008 , to consider what these developments suggest about the conflation of re-distributive politics and identity politics, and what opportunities this might offer civil society actors. We look to make sense of all of this in a wider context that draws from Castells' notion of networked social movements, to identify ways in which our understanding of civil society can match some of the complexity outlined above.

\section{Contextual matters: the emergence and properties of financial capitalism}

To fully appreciate the changing nature and role of civil society it is necessary to grasp the parameters of the latest phase of capitalism, what we here call financial capitalism. Its genesis can be traced back to the early to mid-1970s, symbolized (but not caused) by the quadrupling of oil prices. At the kernel of this transition was the unfolding of a novel class/command dynamic (Scambler, 2007; Scambler, 2012a,b; Scambler and Scambler, 2013). In terms of Habermas' critical theory, system rationalization or lifeworld colonization has not only proceeded apace under financial capitalism, but the subsystem of the economy (and its relations of class) has come to exercise a greater sway over the subsystem of the state (and its relations of command). Money, in short, buys more power under the aegis of financial capitalism. But what is financial capitalism, and why and how is its class/command dynamic salient to civil society and health care policy and 'reform'?

In the 1970s the American abrogation of Bretton Woods and the rise of the Eurodollar freed up money capital from national regulation by central banks; and the international recession drew banks further into the global arena. Commentators wrote of financialization, alluding not only to de-regulation and internationalization, but also to a shift in the distribution of profits from productive to money capital (accompanied by an increase in the external financing of industry), and to a reorientation reaching deep into 'industrial' corporations towards the financial sphere (Carroll, 2008). Industrial capital, in short, had increasingly come to resemble financial capital. Within the banking sector itself, deregulation precipitated capital centralization in banks with global tentacles, whose activities ranged from financial production to speculation in derivatives, while institutional investors controlling capitalized deferred wages became important centres of allocative as well as strategic power' (Carroll, 2008: 56). And this was before the global financial crash of 2008-9.

Members of a hard core or cabal at the centre of Britain's capital executive (CCE), consisting of the CEOs and directors of major (largely transnational) companies, rentiers and, most conspicuously, financiers, now provide financial capitalism's cutting edge. This CCE, in other words, has come to epitomize fine-tuned class action. It has spawned a new breed of the 'super rich' as well as a 'squeezed middle', 'precariat' and a US-like category of the abandoned. This has only been possible via the purchase of ever more power from Britain's political elite (PE), which has become more insistent, even repressive. Even as the PE has lost capability relative to the CCE, it has become more controlling of its publics, so far without risking a crisis of legitimation. It is now plausible to claim that Britain is ruled by oligarchy (i.e. CCE $+\mathrm{PE}=\mathrm{OLIGARCHY).}$

This new assertion of relations of class over those of command suggests a reinvigoration of the former. This is true, we suggest, as far as objective class relations are concerned, but false with reference to subjective class relations. Financial capitalism has witnessed a decline in the salience of class for identity-formation. People 
outside of the ruling oligarchy are less, not more, likely to develop class-consciousness than in the immediate postwar period. This is not just a function of neo-liberal policies and laws to undermine trade unions, full and secure employment, a living wage, welfare statism and so on; it also reflects a cultural shift functional for the oligarchy and its natural allies. Two qualifications are required here. First, we are not arguing that this cultural shift - amounting to a well-documented 'postmodernization' or relativization of culture, as evidenced by a shift towards a politics of recognitions and a shift away from a politics of redistribution (Fraser and Honneth, 2004) is the result of an oligarchic conspiracy (the CCE and PE have in fact rarely needed to conspire in financial capitalism; what Wright Mills (1956) called 'tacit coordination' has easily sufficed). And second, we are not implying either that those who 'labour to live' have lost touch with their class roots and interests. As Houtman et al. (2012) so eloquently show in their comparative study, popular cultural motifs and predispositions have obscured but not supplanted people's sense of class. Class consciousness is dormant or latent but far from a sociological anachronism.

This then is the framework that we apply to the process of NHS reform in England and Wales. We draw upon this framework to enable us to elucidate more clearly upon the very clear and apparent disjuncture between protest sectors within civil society and the (negative) reform of what is widely held to be a collective social good.

\section{England's Health and Social Care Bill/Act}

It is fortunately not necessary to recap on the entire history of the National Health Service (NHS) from its unveiling in 1948 to the present. The 1970s marked the beginnings of a departure from a postwar inter-party consensus on the founding principles of the NHS and its mode of delivery of treatment and care. There was an attempt in the early 1970s to secure greater integration of services than that afforded by the original 'tripartite' division between hospital, general practitioner (GP) and local authority services, (Klein, 2013) but it was the election of Thatcher in 1979 that signalled the intent to force through a more radical programme of 'substantive reform'.

In the early Thatcher years efforts were made to introduce innovative and more 'corporate' management structures, leading observers to write of a 'new managerialism'. Thatcher's commitment to markets, however, led to the passage of the National Health Service and Community Care Act of 1990 (ibid). Implemented the following year, this Act saw the insertion of an 'internal market' into the NHS. This separated the roles of 'purchaser' and 'provider' and was designed to encourage competition between providers of services, including those from the private sector. Often decried as a 'pseudo-market, it sat on a spectrum somewhere between a bureaucratic 'command and control' economy and a private free market. If it was closer to the former, it also broke with precedents. In the event private providers made little headway; but it was a portent of what was to come.

Thatcher's displacement by Major in 1990 precipitated what was to become a more ominous policy innovation, the introduction in 1992 of the Private Finance Initiative (PFI). The PFI was a device that delegated the building of new hospitals and other health care facilities to the private sector, who then leased them back to the NHS, often at exorbitant rates on the back of 20-30 year deals. The advantage to government was that these building and refurbishment programmes did not appear on its books (that is, they represented an investment of private as opposed to public capital). As Pollock (2005) predicted from the outset, it was to prove an expensive way to get facilities on the cheap, and the chickens have now come home to roost. The 'New Labour' regimes of Blair and
Brown pursued PFIs with a vengeance between 1997 and 2010, (Speed and Gabe (2013) demonstrate the family resemblance between labour and coalition government reform plans for the NHS). We are now seeing a number of healthcare facilities coming under threat because of a mix of: (a) austerity measures or 'cuts' following the financial crash, and (b) the levels of mounting indebtedness occasioned by prior PFI commitments. A key effect of successive governments' reliance of PFIs is that many hitherto-public hospitals/facilities are now privately owned.

The result of the 2010 general election was a Cameron/Clegg coalition government allying the Conservatives and Liberal Democrats. Despite an unambiguous pre-election undertaking not to subject the NHS to top-down reform, the new Health Minister, Lansley, published a well rehearsed White Paper (Liberating the NHS) a mere 60 days after the coalition was formed (Timmins, 2012). This was followed by a Health and Social Care Bill that allowed for a potential root-and-branch privatization or recommodification of health care in England (other 'devolved' parts of the UK escaping its jurisdiction). The principal themes of the Bill, specific organizational changes, together with a list of critics' questions, are contained in Box 1. A protracted period of 'debate' in 2012-13 was extended to allow a strategic 'pause' for further consultation. This delay was interpreted by critics of the Bill as a hard-won concession, furnishing an opportunity for reinvigorated resistance, while the coalition saw it as an opportunity to shore up the legitimacy of its reforms. The medical profession, a reluctant recruit to the original concept of an NHS in the 1940s, questioned and then opposed the Bill; but they mustered insufficient conviction to

\section{Box 1}

The Health and Social Care Bill: text and subtext.

Five themes:

1. Strengthening commissioning services

2. Increasing democratic accountability and public voice

3. Liberating provision of health services

4. Strengthening public health services

5. Reforming health and social care's arm's length bodies

Organizational changes

- By April of 2013 the 192 primary care trusts to be abolished and GPs to join commissioning consortia

- Consortia to control $80 \%$ of NHS budget

- Services to be purchased from 'any willing provider'

- All NHS hospital to be foundation trusts by 2014

- Commissioning to be overseen by NHS' financial regulator, 'Monitor'

\section{Critics' questions}

- Why should the new commissioning consortia be 'better' than primary care trust commissioning?

- What will be the role of private companies in relation to commissioning criteria?

- What is the role of 'Monitor' in European Union law?

- How exactly will patients have 'more choice'?

-Where will the efficiency savings come from?

- Will the pursuit of efficiency savings be at the expense of quality? 
scupper it in the face of resolute coalition sponsorship. Bluntly, they were ready for industrial action to defend their pay and conditions but not to safeguard a public NHS. Public protests, which we revisit in detail below, proved similarly ineffective. The Bill became an Act in March of 2013. Later in 2013, the government pushed a (strategically re-written but equivalent) 'regulation 75' through the Houses of Parliament, removing residual obstacles to the unfettered promotion of for-profit health care (see Davis and Tallis, 2013).

These are the bare bones of what happened: some flesh is put on the skeleton below. Before we switch attention to what the passage of this Act says about the enabling and protest sectors of civil society and the public sphere of the lifeworld, a number of critical points of summation and synthesis are in order:

1. Neither the Conservatives nor the coalition regime had a mandate to reform the NHS in the way they have (indeed, Liberal Democrat voters might have expected outright opposition to Lansley's Bill) (see Ashton, 2012). Moreover, it was a reform to be carried out against the background of a programme of NHS efficiency savings announced by the Brown government in mid-2009 and amounting to £15-20 billion in three years starting from April 2011.

2. The combination of majority opposition on the part of the medical, nursing and other health professions, polls showing public concern, and a sequence of campaigns, marches and protests were circumvented without a crisis of legitimation ever seeming truly imminent (see Huitson, 2013 for a partial explanation of this).

3. Notwithstanding vigorous activity within civil society's protest sector and belated opposition on the part of the health professions, the unresponsiveness or passivity of the wider public may have been due in part to: (a) the continued use of a rhetoric of 'patient-centredness' highlighted by the Thatcher and New Labour regimes, and (b) a tendency to view health professionals rather than the public as the primary target of the reforms (Speed, 2011; Speed and Gabe, 2013).

4. Although a small band of people from all walks of life, including medicine and academia, were recruited or coopted to the government cause, there is no doubt that 'best evidence' on comparative health care testified to the regressive nature of the Health and Social Care Bill: this was policy based evidence, not evidence based policy (see Pollock et al., 2011; Reynolds and McKee, 2012).

5. As Leys and Player (2011) have shown, for-profit providers were not only lobbying the Conservative Party prior to the Bill, but were integral to its thrust and composition (not least via the Future Forum); they were lining up to takeover NHS services (the leading private companies ('H5', accounting between them for $80 \%$ of private hospitals and $85 \%$ of private beds) formed an alliance as early as December of 2010). Much of this clandestine activity presented as internal to the NHS rather than as external lobbying.

6. The likely medium-to-long term sequelae of the Act are fundamental. Scott-Samuel (2012) spelt these out early on in a letter to the Guardian:

the NHS will become a publicly funded budget and a brand name for a subcontracting operation for competing private organizations, subject to European competition laws that will allow private companies to predominate over other - third sector - providers.

(a) The post-credit crash NHS has a more or less fixed budget, so services of 'low clinical priority' will cease to be free.

(b) This will lead to a market for health insurance, affordable for the affluent, which will drive up costs (administrative, fees, private profits). (c) Personal health budgets will lead to personal charges as commissioning groups will operate on an individual basis in order to be compatible with the insurance companies (in other words, no more population-based pooling of risk).

The question as to why a manifestly regressive re-commodification of health care in England was accomplished so swiftly with so little effective resistance bears heavily on lifeworld versus system dynamics. It begs questions of what is left of civil society and the public sphere? And what prospects for their future and that of substantive, participatory or deliberative democracy?

\section{The 'new resistance' and civil society}

If Habermas' description of the public sphere of the lifeworld as 're-feudalized' is questionable, there is no denying that lifeworld rationalization has been outpaced and subdued by system rationalization in financial capitalism; and, to reiterate, our assertion in this contribution is that this is largely down to the contemporary class/command dynamic. While we have argued that objective class relations show an enhanced explanatory potential, however, we have accepted that subjective class relations show a diminished return. So what ramifications does this have for old versus new movement resistance to class/command strategic moves like the Health and Social Care Act?

It is evident that the ubiquitous neo-liberalism accompanying and providing ideological cover for financial capitalism has become the last 'grand narrative' (Lyotard, 1984). In The New Conservatism, Habermas (1994) argues that what we earlier called the postmodernization of culture, rather than constituting a form of liberation, has made it more difficult to construct a compelling rational opposition to the status quo. Neo-liberalism has become the default option, the grand narrative that need not speak its name. Once viable alternatives, like communism or socialism, have become pick-and-mix petit narratives. Existing alternatives such as Scandinavian models of welfare, whilst they offer a more optimistic narrative, do not draw from a core ideology of socialism or communism but rather are built on models of individualism which draw on welfare mechanisms that support individuals rather than any wider collective sense of support (see Bambra, 2011 for a consideration of some of the puzzles associated with Scandinavian models). We are stuck with neo-liberalism as the only possible worldview, anchored though it is in the vested interests of the oligarchy and its new middle class allies.

The increases in inequalities of wealth and income during financial capitalism are startling. According to the Report of the National Equality Panel, An Anatomy of Inequality in the UK (2010), the top decile of the UK population is now 100 times as wealthy as the bottom decile. The Interim Report of the High Pay Commission (High Pay Commission, 2011) bears testimony to what can only be defined as an increasingly unconstrained and voracious greed (Scambler, 2009). Dominant among Britain's top 0.1\% of income 'earners' are finance and business workers and company directors. FTSE 100 chief executives enjoyed average total remuneration of over $£ 4.2 \mathrm{~m}$ in 2009-10. In 2010, FTSE 100 CEO pay was 145 times the average salary for workers, and it is on track to be 214 times the average salary by 2020 (Scambler, 2012a,b).

In the wake of these escalating inequalities have ineluctably come increases in health inequalities (Scambler, 2012a,b). The Health and Social Care Act - itself one of a close-knit family of welfare cuts and reforms (e.g. the switch to universal credit, public sector pay and pension curtailments and the 'bedroom tax') will serve to cement advantage and disadvantage. And yet no crisis of legitimation seems imminent. Why and how is it that financial 
capitalism's class/command dynamic has not precipitated a legitimation crisis? We draw attention to:

- the insinuating, mediated presentation of events orchestrated by the likes of opportunistic, post-nation-state, profit-oriented moguls like Murdoch (Watson and Hickman, 2012);

- the cultural downgrading of any putative oppositional grand narrative (ADD REFERENCE);

- an electoral ambivalence re-political versus cultural commitments (Houtman et al., 2012);

- an engineered detachment and scapegoating of a 'displaced segment' of the working class - the US-style abandoned or 'abject' (Scambler and Higgs, 1999).

- the profligate and nascent rise of a neoliberal individualism that enables the 'deregulation, privatization and withdrawal' of government from health and welfare provision (Harvey, 2005).

That no legitimation crisis has occurred in Britain does not mean either that it will not do so in the future (Scambler and Scambler, 2013) or that there has been no resistance to measures taken under the umbrella of austerity since 2010 . Moreover there is a new volatility to world events, as is evidenced at the time of writing by a myriad of protests from Istanbul to Sao Paulo. As an editorial in the Observer (2013: 23 June) concluded:

'There are seeds of a legitimacy crisis brewing. People are acutely aware that while they are struggling to make ends meet, the elite are pulling away: MPs feathering duck houses; corporations avoiding tax; bankers taking home million pound bonuses, seemingly unaffected by the crisis they caused. At the same time, stoked by the toxic political debate, resentment has grown about a perceived underclass of welfare cheats and immigrants milking the benefits system'.

The four points made above are synthesized in this editorial paragraph.

One feature of the round of protests in financial capitalism is captured by Castells' (2012) concept of 'networked social movements' introduced earlier. But we discern a paradox, which we shall call the paradox of means and ends. While the means for mobilizing people across a broad arch or range of 'potentials' have escalated in the network society, the ends have become obfuscated. This may need some unpacking. We are suggesting, first, that information and communication technologies (ICTs) in globally networked, 24/7 societies like Britain, already featuring digital media well beyond the likes of Facebook and Twitter (Orton-Johnson and Prior, 2013), make it easier for people to come together, organize and resist via the enabling and protest sectors of civil society, notwithstanding increasingly repressive state, command and ultimately oligarchic surveillance (often masquerading as anti-terrorist measures). But we also contend, second, that the ends people unite to pursue tend to be negative (i.e. against something) rather than positive (i.e. for something); and insofar as they are positive, to be tactical (i.e. to halt the privatization of the English NHS) rather than strategic (i.e. to create a better society). This paradox might best be illustrated by the 'occupation movement', which was initiated in Wall Street and rapidly spread to cities like London. Those who camped in the public space around St Pauls' Cathedral were clearer on what they opposed than what they aspired to. This is to recognize the difficulties of constructing consensus out of a pick and mix of petit narratives. As Castells suggests, however, it is a pragmatic strength as well as a weakness.

Sennett (2012) offers a thoughtful and subtle analysis of the changing nature and usage of public space, again using the occupy movement for illustration. Tents and sleeping bags, he argues, were the 'weapons' with which the occupy movement tested cities' limits on freedom of assembly (including 'Draconian' London). The St Paul's protesters exploited an ambiguity between secular and sacred space:

'at first the Church fathers were minded to call in the police; this violated, however, a tradition established in the Middle Ages that a church should provide sanctuary in the city, offering refuge in cloister gardens for the poor and outcast. Citing this tradition, the Dean of St Paul's argued against his superiors, and resigned; they too dithered. Eventually the Archbishop of Canterbury, Rowan Williams, weighed in, arguing that sanctuary applied to political protesters. The ambiguity, though, was that the Occupiers were not seeking invisibility, as an outcast might; whenever a congruent went into church to pray, he or she passed next to an often noisy anti-capitalist gathering'.

Sennett's point is consonant with Castells' analysis: space in financial capitalism requires rethinking. Collective, oppositional activity - whether in the protest sector of civil society or, more ambitiously, in the lifeworld's public sphere - must be re-anchored in actual time and space.

\section{Concluding comments}

This paper promotes the need for rethinking civil society. It adopts a Habermasian frame to this end. The class/command dynamic implies, with (early) Habermas, that civil society is pitted against class as well as command relations. The relative ineffectiveness of 'noisy', oppositional activity to a manifestly regressive Health and Social Care Bill in England through 2012-3, a classic instance of policy-based evidence, suggests a non-permeable border between civil society's protest sector and the broader public sphere. Expressed differently, this activity did not translate into influence (the steering medium of the public sphere). It was blocked by the oligarchy. Disgruntled networks on Twitter reverberated with condemnations of mass media passivity in the face of the recommodification of English health care, most notably on the part of the BBC (Huitson, 2013). A 'subterranean politics' might have 'bubbled up' in civil societies in other parts of the world, even of Europe, but it remains largely latent and of indeterminate effect in Britain, even after the riots of August 2011 (Kaldor and Selchow, 2012).

But this has discomforting ramifications too for the sociology of health, illness and health care. Scambler (1996) has argued that sociology only makes sense as part of a reconstructed Enlightenment project oriented to a decolonization or rationalization of the lifeworld. Scambler et al. (2012) have developed this thesis to make a case for what they call 'action sociology', a fifth type to append to Burawoy's (2005) four types of sociology. Burawoy's important and seminal call for a more 'public sociology', it is argued, does not go far enough. When, for example, policy-based evidence displaces evidence-based policy as a strategic colonizing act, as in the case of the passing of the Health and Social Care Act, it is not enough to shrug one's sociological shoulders. Nor is publishing another journal article sufficient. What is required, we maintain, is political engagement and input: sociologists, qua activists, must take their work into the protest sector of civil society and thence to the public sphere of the lifeworld. Therein influence lies, and moreover, therein the power of the oligarchy can be mobilized against and resisted.

But a case might be made also for a sixth type of sociology, requiring a shift within the discipline to focus on the development of viable, credible, evidence-based alternatives to those presented by the neo-liberal elite. This picks up on Giddens' (1990) concept of 
'utopian realism'. If utopianism per se smacks of totalitarianism, Giddens' notion, and ours, insist on the exploration of alternatives to present orthodoxies. It is sociology's duty too to spell out options. In the context of this paper, action sociology demands resistance to the implementation of the Health and Social Care Act, but alongside this there is the need for an evidence- based examination of rival and optimal futures for delivering health care. The flexible inventiveness of the nefarious forces of darkness implementing the NHS reforms need to be challenged through the development of equally flexible and inventive alternatives. Action sociology is necessary but not sufficient in this cause. Now, there's a challenge worthy of Enlightenment philosophy.

\section{Q7 Uncited references}

Davis et al., 2013; Landes, 1998.

\section{References}

Ashton, J., 2012. The art of medicine: defending democracy and the National Health Service. Lancet. http://dx.doi.org/10.1016/S0140-6736(12)60287-6.

Bambra, C., 2011. Health inequalities and welfare state regimes: theoretical insights on a public health 'puzzle'. J. Epidemiol. Community Health 65 (9), 740-745.

Burawoy, M., 2005. For public sociology. Am. Sociol. Rev. 70 (1), 4-28.

Carroll, W., 2008. The corporate elite and the transformation of financial capital: view from Canada. In: Savage, M., Williams, K. (Eds.), Remembering Elites. Blackwell, Oxford.

Castells, M., 2012. Networks of Outrage and Hope: Social Movements in the Internet Age. Polity Press, Cambridge.

Davis, J., Tallis, R. (Eds.), 2013. NHS SOS: How the NHS was Betrayed - and How We can Save It. Oneworld, London.

Davis, J., Banks, I., Wrigley, D., Peedell, C., 2013. Act now against the new NHS competition regulations. Br. Med. J. 346, 25.

Edwards, G., 2004. Habermas and social movements: what's 'new'? In: Crossley, N. Roberts, J. (Eds.), After Habermas: New Perspectives on the Public Sphere. Blackwell, Oxford.

Farnsworth, K., Irving, Z., 2012. Varieties of crisis, varieties of austerity: social policy in challenging times. J. Poverty Soc. Justice 20 (2), 133-147.

Fraser, N., Honneth, A., 2004. Redistribution or Recognition?: a Politicalphilosophical Exchange. Verso, London.

Giddens, A., 1990. Consequences of Modernity. Polity Press, Cambridge.

Glennerster, H., 2013. Financing future welfare states: a new partnership model? In: Stoker, G., Kippin, H., Griffiths, S. (Eds.), Public Services: A New Reform Agenda. Bloomsbury, London.

Habermas, J., 1984. Theory of Communicative Action. Vol. 1: Reason and Rationalization of Society. Heinemann, London.

Habermas, J., 1987. Theory of Communicative Action. In: Lifeworld and System: a Critique of Functionalist Reason, vol. 2. Polity Press, Cambridge.

Habermas, J., 1989. The Structural Transformation of the Public Sphere: an Enquiry into a Category of Bourgeois Society. Polity Press, Cambridge.

Habermas, J., 1992. Further reflections on the public sphere. In: Calhoun, C. (Ed.), Habermas and the Public Sphere. MIT Press, Cambridge, MA.

Habermas, J., 1996. Between Facts and Norms: Contributions to Discourse Theory. Polity Press, Cambridge.

Habermas, J., 1994. The New Conservatism. Polity Press, Cambridge.

Harvey, D., 2005. A Brief History of Neoliberalism. Oxford University Press, Oxford.

Houtman, D., Achterberg, P., Derks, A., 2012. Farewell to the Leftist Working Class. Transaction Publishers, New Brunswick.
Huitson, O., 2013. Hidden in plain sight. In: Davis, J., Tallis, R. (Eds.), NHS SOS: How the NHS was Betrayed - and How We can Save it. Oneworld, London.

Kaldor, M., Selchow, S., 2012. The 'Bubbling up' of Subterranean Politics in Europe. LSE, London.

Klein, R., 2013. The New Politics of the NHS: From Creation to Reinvention, seventh ed. Radcliffe Publishing, London.

Landes, D., 1998. Wealth and Poverty of Nations. Little, Brown \& Co, London.

Leys, C., Player, S., 2011. The Plot Against the NHS. The Merlin Press, London.

Lyotard, J.F., 1984. The Postmodern Condition. Manchester University Press, Manchester.

Mayhew, L., 1997. The New Public: Professional Communication and the Means of Social Influence. Cambridge University Press, Cambridge.

Mills, C.W., 1956. The Power Elite. Oxford University Press, Oxford.

National Equality Panel, 2010. An Anatomy of Economic Inequality in the UK. National Inequality Panel, London.

Oldenburg, R., 1997. The Great Good Place: Cafes, Shops, Community Centre, Beauty Parlours, General Stores, Bars, Hangouts and How They Get You Through the Day. Marlowe \& Co, New York.

Orton-Johnson, K., Prior, N. (Eds.), 2013. Digital Sociology. Palgrave Macmillan, London. Pollock, A., 2005. NHS Plc: the Privatisation of Our Health Care. Verso, London.

Pollock, A., Price, D., Roderick, P., Treuherz, T., McCoy, D., McKee, M., Reynolds, L., 2011. How the Health and Social Care Bill 2011 would end entitlement to comprehensive health care in England. Lancet 379, 387-389.

Reynolds, L., McKee, M., 2012. Opening the oyster. Clin. Med. 12 (2), 128-132.

Scambler, G., 1996. The 'project of modernity' and the parameters for a critical sociology: an argument with illustrations from medical sociology. Sociology 30 (3), 567-581.

Scambler, G., 2007. Social structure and the production, reproduction and durability of health inequalities. Soc. Theory Health 5 (4), 297-315.

Scambler, G., 2009. Capitalists, workers and health: illness as a 'side-effect' of profitmaking. Soc. Theory Health 7 (2), 117-128.

Scambler, G., 2012a. Review article: health inequalities. Sociol. Health Illn. 34 (1), 130-146.

Scambler, G., 2012b. Resistance in unjust times: archer, structured agency and the sociology of health inequalities. Sociology 47 (1), 142-156.

Scambler, G., Higgs, P., 1999. Stratification, class and health: class relations and health inequalities in high modernity. Sociology 33 (2), 275-296.

Scambler, G., Kelleher, D., 2006. New health and social movements: issues of representation and change. Crit. Public Health 16 (3), 219-231.

Scambler, G., Scambler, S., 2013. Marxism, critical realism and health inequalities. In: Cockerham, W. (Ed.), Medical Sociology on the Move: New Directions in Theory. Springer, New York.

Scambler, G., Scambler, A., Scambler, N., Scambler, S., Scambler, R., Scambler, M., 2012. The Case for Action Sociology. www.cost-ofliving.net/a-case-for-actionsociology.

Scott-Samuel, A., 20 January 2012. Where the NHS is heading. Letter in Guardian.

Sennett, R., 2012. The Occupy Movements have Dramatized Questions about Public Space: Who Owns It? and Who can Use it?. http://blogs.Ise.ac.uk/ politicsandpolicy/archives/27607.

Speed, E., 2011. Applying soft bureaucracy to rhetorics of choice: UK NHS 19832007. In: Clegg, S., Harris, M., Hopfl, H. (Eds.), Managing Modernity: The End of Bureaucracy? Oxford University Press, Oxford.

Speed, E., Gabe, J., 2013. The Health and Social Care Act for England 2012: the extension of 'new professionalism'. Crit. Soc. Policy 33 (3), 566-576.

Taylor-Gooby, P., 2013. Public service reform and social inequality. In: Stoker, G. Kippin, H., Griffiths, S. (Eds.), Public Services: a New Reform Agenda. Bloomsbury, London.

Thompson, J., 1993. Review article: the theory of the public sphere. Theory Cult. Soc. $10,173-189$.

Timmins, N., 2012. Never Again" the Story of the Health and Social Care Act 2012: a Study in Coalition Government and Policy Making. Institute for Government \& King's Fund, London.

Watson, T., Hickman, M., 2012. Dial M for Murdoch: News Corporation and the Corruption of Britain. Allen Lane, London. 